\title{
Influence of Cultural Conditions on the Cellular Biovolume and Gelatinous Sheath Volume of Staurastrum arctiscon (Charophyceae)
}

\author{
Kei SUZUKI*, Makoto KOJIMA**, Naoyuki KISHIMOTO**, Satoshi ICHISE***, Seiko \\ FURUTA*** \\ *Department of Environmental Solution Technology, Graduate School of Science and \\ Technology, Ryukoku University, Shiga 520-2194, Japan \\ **Department of Environmental Solution Technology, Faculty of Science and Technology, \\ Ryukoku University, Shiga 520-2194, Japan \\ ***Lake Biwa Environmental Research Institute, Shiga 520-0022, Japan
}

\begin{abstract}
This study investigated the influence of cultural conditions on the cellular biovolume $\left(V_{C}\right)$ and gelatinous sheath volume $\left(V_{G}\right)$ of Staurastrum arctiscon (Charophyceae) and its growth characteristics during laboratory culturing. A unialgal culture isolated from Lake Biwa was incubated in modified M11 medium containing various concentrations of nitrogen and phosphorous in the form of nitrate and phosphate $(0.01$ or $0.1 \mathrm{mg} \mathrm{P} / \mathrm{L})$. The N/P mass ratio of the medium and incubation temperature ranges were $5-100$ and $5-35^{\circ} \mathrm{C}$, respectively. $V_{C}$ was lower at higher incubation temperature and higher nitrate concentrations, whereas $V_{G}$ increased with temperature. As $V_{C}$ and $V_{G}$ changed, the size of the gelatinous sheath increased relative to the cellular biovolume $\left(V_{R}\right)$ with the water temperature and nitrate concentration. The enhanced growth rate and net production rate with a rising temperature were considered to contribute to the decreased $V_{C}$ and increased $V_{G}$. The positive effect of nitrate concentration on $V_{G}$ was believed to be attributable to the enhanced net production rate with higher nitrate concentrations.
\end{abstract}

Keywords: gelatinous sheath, Lake Biwa, N/P ratio, phytoplankton

\section{INTRODUCTION}

Phytoplankton and aquatic plants account for most of the primary production in lakes. The phytoplankton population density is not very high in Lake Biwa, Japan, although the primary production by phytoplankton in offshore zones of the lake is believed to account for a significant proportion of the total production because the lake is deep and the euphotic zone reaches depths of $10-20 \mathrm{~m}$. Nozaki (2002) reported that the areal net phytoplankton production in the pelagic zone in Lake Biwa was almost equal to or exceeded the areal net production in the littoral zone, where most of the net production was attributed to periphyton. Therefore, the influence of primary production by phytoplankton and their behavior in the field are important for understanding organic pollution in lakes.

Changes in the stratification structure due to climate change (Kumagai, 2008; Sakamoto, 2011) and changes in the nitrogen to phosphorus ratio (N/P ratio) (Tsuda et al., 2006; Hsieh et al., 2010) have been reported in Lake Biwa. To investigate the ecological impact of environmental change in Lake Biwa, Hsieh et al. (2010) reported that the phytoplankton community shifted dramatically in response to changes in trophic status driven by phosphorus loadings and physical properties of the water column driven by warming. Furthermore, Ichise et al. (2010a) reported that the mean cellular biovolume

Address correspondence to Kei Suzuki, Department of Environmental Solution Technology, Graduate School of Science and Technology, Ryukoku University, Email: kei_suzuki@me.com

Received May 18, 2012, Accepted October 10, 2012. 
tended to decrease in Lake Biwa. In general, smaller organisms show higher specific growth rates (Kagami and Urabe, 2001; Belgrano et al., 2002). Therefore, the predominance of smaller phytoplankton results in higher specific productivity (Yvon-Durocher et al., 2011). In addition to the succession of the phytoplankton community, environmental changes may influence the cellular biovolume of the same phytoplankton species because it is often observed that the same phytoplankton species show diverse body size according to environmental factors in the habitat. However, the mechanism of this cause-effect relationship is unclear at present. Thus, it is necessary to clarify the relationship between environmental factors and the cellular biovolume.

In addition, Ichise et al. (2010a) reported that phytoplankton with gelatinous sheaths tended to increase in Lake Biwa. Lange (1976) suggested that the formation and retention of a voluminous sheath provides a microenvironment around the algal cell where essential nutrients, which are present only at submarginal levels in the surrounding water, can become concentrated and made readily available to the cell. In addition, Fogg (1983) reported that extracellular phytoplankton photosynthetic products occasionally accounted for about $25 \%$ of the primary production. Thus, the main factors affecting gelatinous sheath production also need to be explored to understand organic pollution due to production within lakes. Light, nutrients, and temperature are important factors that affect photosynthesis (Urabe et al., 1999). Nitrogen and phosphorus in particular are the major nutrients that affect primary production (Smith, 1979; Downing, 1997; Hall et al., 2005). Therefore, this study investigated the influence of water temperature, nitrogen, and phosphorus on the cellular biovolume and gelatinous sheath volume of Staurastrum arctiscon (Charophyceae).

The large green algae like Staurastrum spp. are considered to be the main primary producers in the food web of Lake Biwa (Kagami and Urabe, 2001; Sekino et al., 2007). $S$. arctiscon is a large green alga with a gelatinous sheath (Fig. 1A) and its population density in Lake Biwa has increased from an average of 0.3 cells $/ \mathrm{mL}$ in the $1980 \mathrm{~s}$ to 0.4 cells $/ \mathrm{mL}$ in the $1990 \mathrm{~s}$ and to 2.3 cells $/ \mathrm{mL}$ in the $2000 \mathrm{~s}$. Accordingly, S. arctiscon was examined in this study.

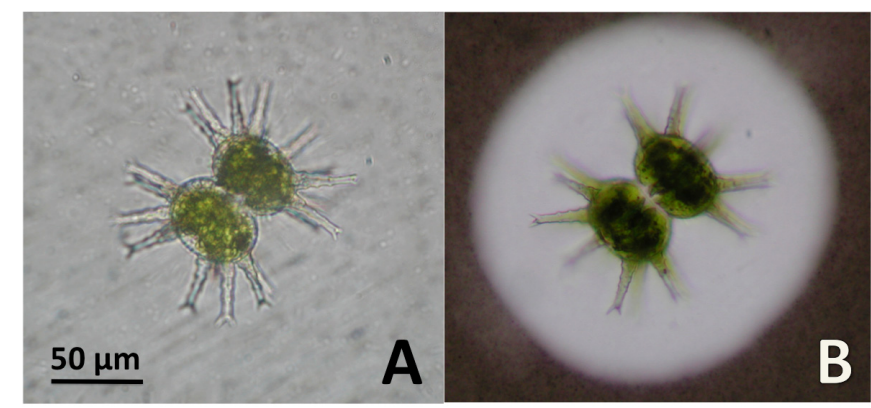

Fig. 1 - S. arctiscon on a slide glass without Chinese ink (A) and with Chinese ink (B). 


\section{MATERIALS AND METHODS}

\section{Phytoplankton species examined}

A unialgal culture of $S$. arctiscon, isolated from Lake Biwa, was cultured in M11 medium (Hagiwara, 1984) containing $16.5 \mathrm{mg} \mathrm{N} / \mathrm{L}$ of nitrate as a single nitrogen source and $1.78 \mathrm{mg} \mathrm{P} / \mathrm{L}$ of phosphate as a single phosphorus source, while the calcium chloride dihydrate $\left(\mathrm{CaCl}_{2} \cdot 2 \mathrm{H}_{2} \mathrm{O}\right)$ concentration was changed from 40 to $30 \mathrm{mg} / \mathrm{L}$. Briefly, 100 $\mathrm{mL}$ of modified M11 medium was poured into Erlenmeyer flasks with screw caps (200 $\mathrm{mL}$ ) and autoclaved at $121^{\circ} \mathrm{C}$ for $20 \mathrm{~min}$. An aliquot (1 or $\left.2 \mathrm{~mL}\right)$ of $S$. arctiscon preculture was inoculated into each Erlenmeyer flask. The basic culture conditions were incubation for $20-26$ days at $20^{\circ} \mathrm{C}$ with photosynthetic active radiation (PAR) at 36.5 $\mu \mathrm{mol} / \mathrm{m}^{2} / \mathrm{s}$ and a light:dark cycle of $12: 12 \mathrm{~h}$ in a table top biotron (LH-55-RDS; Nippon Medical \& Chemical Instruments, Japan). The pre-cultured S. arctiscon was cultured again for 2 weeks in modified M11 medium without nitrogen and phosphorus to establish starvation. Next, the starved cells were used for incubation experiments. All incubation experiments were conducted in triplicate using batch cultures with gentle shaking every 2 or 3 days. The culture conditions were modified to determine the effects of the N/P mass ratio of the medium $(5-100)$, incubation temperature $\left(5-35^{\circ} \mathrm{C}\right)$, and the concentration of phosphorus $(0.1 \mathrm{mg} \mathrm{P} / \mathrm{L}$ or $0.01 \mathrm{mg} \mathrm{P} / \mathrm{L})$. PAR was set at 36.5 $\mu \mathrm{mol} / \mathrm{m}^{2} / \mathrm{s}$ in these cultures. The nitrogen and phosphorus concentrations were adjusted by changing the amounts of sodium nitrate $\left(\mathrm{NaNO}_{3}\right)$ and dipotassium hydrogenphosphate $\left(\mathrm{K}_{2} \mathrm{HPO}_{4}\right)$, respectively. The population density of $S$. arctiscon was monitored every $2-3$ days using a plankton counting plate with a stereomicroscope (CX41LF; Olympus Optical, Japan).

\section{Estimation of the specific growth rate}

The specific growth rate of $S$. arctiscon was estimated from the slope of the regression line of equation (1) using population density data from the logarithmic growth phase,

$$
\ln M=\alpha+\mu t
$$

Where, $\mu$ is the specific growth rate (per day), $M$ is the population density of $S$. arctiscon (cells $/ \mathrm{mL}$ ), $\alpha$ is an intercept, and $t$ is the incubation period (days). The dependency of the specific growth rate on the nutrient concentration followed the Monod equation (2). The coefficients of the equation were determined using a Lineweaver-Burk plot (3),

$$
\begin{aligned}
& \mu=\frac{\mu_{\max } C}{K+C} \\
& \frac{1}{\mu}=\frac{1}{\mu \max }\left(\frac{K}{C}+1\right)
\end{aligned}
$$

Where, $\mu_{\max }$ is the maximum specific growth rate (per day), $C$ is the nutrient concentration $(\mathrm{mg} / \mathrm{L})$, and $K$ is the half-saturation constant $(\mathrm{mg} / \mathrm{L})$.

\section{Volume measurement}

Several drops of the culture solution containing S. arctiscon and Chinese ink diluted 
threefold with distilled water were placed on a slide with a frame and a 1-mm-interval scale. The slide was covered with a cover slip and the phytoplankton were observed using a digital microscope (VH-5000; Keyence, Japan) (Fig. 1B). We measured the lengths of the major and minor axes of the cell and gelatinous sheath, and the radius and height of branched protrusions using a computer program (VH-H1A5; Keyence, Japan). The total volume, cellular biovolume, and gelatinous sheath volume of $S$. arctiscon (6) were calculated using the following equations:

$$
\begin{aligned}
& V_{T}, V_{E}=\frac{\pi}{6} a b 2 \\
& V_{B}=r \times r \times \pi \times h \\
& V_{C}=V_{E}+n V_{B} \\
& V_{G}=V_{T}-V_{C}
\end{aligned}
$$

Where, $V_{T}$ is the total volume $\left(\mu \mathrm{m}^{3} /\right.$ cell $), V_{E}$ is the volume of the ellipsoidal part of a cell $\left(\mu \mathrm{m}^{3} /\right.$ cell $), a$ is the major axis of an ellipsoid $(\mu \mathrm{m}), b$ is the minor axis of an ellipsoid $(\mu \mathrm{m}), V_{B}$ is the volume of a branched protrusion $\left(\mu \mathrm{m}^{3} /\right.$ protrusion $), r$ is the radius of a branched protrusion $(\mu \mathrm{m}), h$ is the height of a branched protrusion $(\mu \mathrm{m}), V_{C}$ is the cellular biovolume ( $\mu \mathrm{m}^{3} /$ cell), $V_{G}$ is the gelatinous sheath volume $\left(\mu \mathrm{m}^{3} /\right.$ cell), and $n$ is the number of branched protrusions per cell ( 30 per cell). The size of the gelatinous sheath relative to the cellular biovolume $\left(V_{R}\right)$ was also determined using equation (8).

$$
V_{R}=\frac{V_{G}}{V_{C}}
$$

\section{RESULTS}

\section{Growth characteristics of $S$. arctiscon}

Figure 2 shows the specific growth rate of $S$. arctiscon as a function of water temperature, nitrate concentration, and phosphate concentration. The optimum growth temperature was $25^{\circ} \mathrm{C}$. The responses of the specific growth rate to nitrate and phosphate concentrations resembled Monod's equation. The half-saturation constants were estimated to be $K_{N}=0.076 \mathrm{mg} \mathrm{N} / \mathrm{L}$ for nitrate and $K_{P}=0.011 \mathrm{mg} \mathrm{P} / \mathrm{L}$ for phosphate. Thus, $S$. arctiscon growth was weaker at high temperatures and with phosphate limitation, but stronger with nitrate limitation when compared with $S$. dorsidentiferum (optimum temperature $30^{\circ} \mathrm{C}, K_{N}=0.091 \mathrm{mg} \mathrm{N} / \mathrm{L}, K_{P}=0.0075 \mathrm{mg} \mathrm{P} / \mathrm{L}$ : Suzuki et al., 2012). 

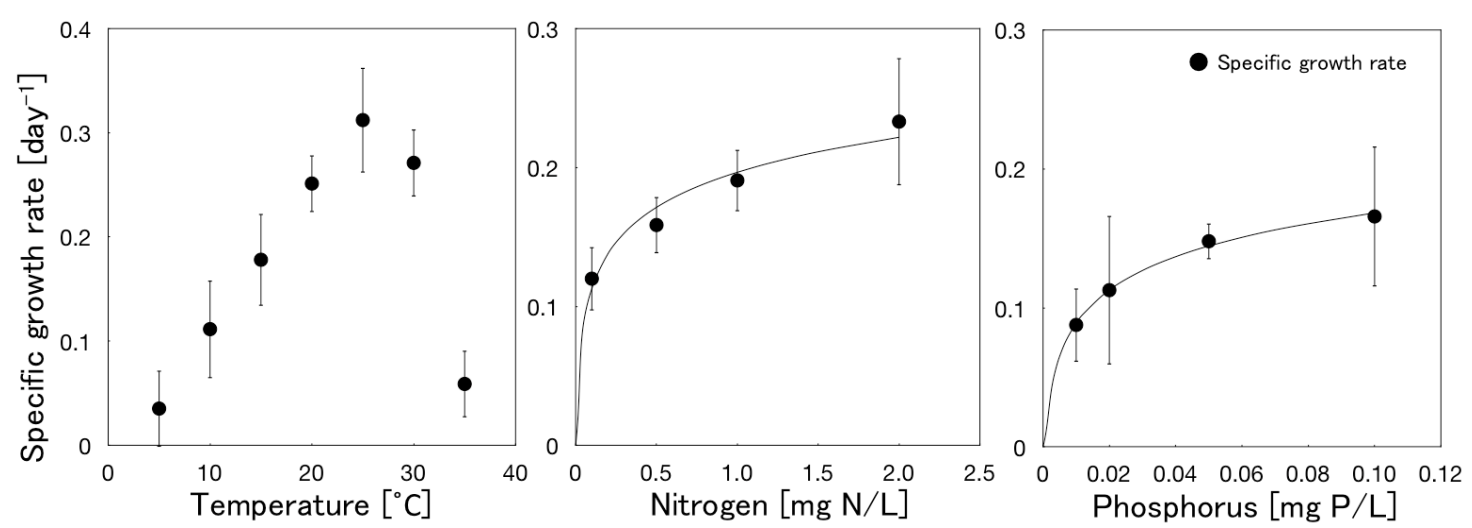

Fig. 2 - Specific growth rate of $S$. arctiscon as a function of water temperature, nitrate concentration, and phosphate concentration. Error bars indicate the standard deviations for triplicate cultures.

\section{Effects of water temperature and nutrients on the cellular biovolume and total volume}

Table 1 shows $V_{G}$ and $V_{C}$ results. A higher temperature appeared to increase $V_{G}$ and to decrease $V_{C}$ in Table 1 . However, the effects of phosphate concentration and the N/P mass ratio on $V_{G}$ and $V_{C}$ were not clear in culture medium.

The $V_{R}$ as a function of the $\mathrm{N} / \mathrm{P}$ mass ratio and water temperature are shown in Fig. 3. Like $V_{G}, V_{R}$ seemed to increase with a rise in temperature. However, the effects of the phosphate concentration and $\mathrm{N} / \mathrm{P}$ mass ratio on $V_{R}$ produced no clear trend.

Multiple regression analysis was applied to $V_{G}, V_{C}$, and $V_{R}$ using the water temperature, nitrate concentration, and phosphate concentration as predictor variables (Table 2). The water temperature had positive regression coefficients with $V_{G}$ and $V_{R}$, but a negative regression coefficient with $V_{C}$ at $p<0.05$. Rhee and Gotham (1981) observed that $V_{C}$ of a green algal species Scenedesmus sp. decreased with an increase in temperature. The relationship between $V_{C}$ of $S$. arctiscon and water temperature was the same as that of Scenedesmus sp. The nitrate concentration had positive regression coefficients with $V_{G}$ and $V_{R}(p<0.05)$, whereas it had no significant regression coefficient with $V_{C}$. The phosphorus concentration had no significant regression coefficients with all volumes. Thus, $V_{C}$ decreased with rising water temperature, while the gelatinous sheath production was enhanced with rising water temperature and nitrate concentration, which resulted in an increase in $V_{R}$. 
Table 1 - Gelatinous sheath volume $\left(V_{G}\right)\left[\times 10^{3} \mu \mathrm{m}^{3} /\right.$ cell $]$ and cellular biovolume $\left(V_{C}\right)\left[\times 10^{3} \mu \mathrm{m}^{3} /\right.$ cell $]$ of $S$. arctiscon. N/P is the N/P mass ratio of the culture medium, while $\mathrm{St}$ indicates starvation. Ranges indicate the standard deviations for triplicate cultures.

\begin{tabular}{|c|c|c|c|c|c|c|}
\hline \multicolumn{7}{|c|}{$V_{G}\left[\times 10^{3} \mu \mathrm{m}^{3} /\right.$ cell $]$} \\
\hline \multirow[b]{2}{*}{$\mathrm{N} / \mathrm{P}$} & \multicolumn{3}{|c|}{ Low $\mathrm{P}$ concentration $(0.01 \mathrm{mg} \mathrm{P} / \mathrm{L})$} & \multicolumn{3}{|c|}{ High $\mathrm{P}$ concentration $(0.1 \mathrm{mg} \mathrm{P} / \mathrm{L})$} \\
\hline & $15^{\circ} \mathrm{C}$ & $20^{\circ} \mathrm{C}$ & $25^{\circ} \mathrm{C}$ & $15^{\circ} \mathrm{C}$ & $20^{\circ} \mathrm{C}$ & $25^{\circ} \mathrm{C}$ \\
\hline St & \multicolumn{6}{|c|}{$1190 \pm 281$} \\
\hline 5 & $992 \pm 303$ & $1239 \pm 306$ & $1940 \pm 597$ & $777 \pm 192$ & $1169 \pm 418$ & $1068 \pm 296$ \\
\hline 10 & $991 \pm 396$ & $1078 \pm 407$ & $1389 \pm 411$ & $903 \pm 297$ & $1123 \pm 352$ & $1717 \pm 327$ \\
\hline 30 & $911 \pm 297$ & $704 \pm 171$ & $1470 \pm 324$ & $924 \pm 311$ & $1087 \pm 307$ & $1263 \pm 240$ \\
\hline 50 & $1259 \pm 279$ & $927 \pm 164$ & $2043 \pm 372$ & $1448 \pm 561$ & $1659 \pm 658$ & $1412 \pm 303$ \\
\hline 100 & $1238 \pm 270$ & $797 \pm 109$ & $1863 \pm 249$ & $1428 \pm 380$ & $1106 \pm 660$ & $1744 \pm 263$ \\
\hline \multicolumn{7}{|c|}{$V_{C}\left[\times 10^{3} \mu \mathrm{m}^{3} /\right.$ cell $]$} \\
\hline & \multicolumn{3}{|c|}{ Low P concentration $(0.01 \mathrm{mg} \mathrm{P} / \mathrm{L})$} & \multicolumn{3}{|c|}{ High P concentration $(0.1 \mathrm{mg} \mathrm{P} / \mathrm{L})$} \\
\hline $\mathrm{N} / \mathrm{P}$ & $15^{\circ} \mathrm{C}$ & $20^{\circ} \mathrm{C}$ & $25^{\circ} \mathrm{C}$ & $15^{\circ} \mathrm{C}$ & $20^{\circ} \mathrm{C}$ & $25^{\circ} \mathrm{C}$ \\
\hline St & \multicolumn{6}{|c|}{$111 \pm 23$} \\
\hline 5 & $107 \pm 20$ & $89 \pm 15$ & $90 \pm 14$ & $109 \pm 20$ & $94 \pm 17$ & $103 \pm 25$ \\
\hline 10 & $116 \pm 19$ & $95 \pm 14$ & $89 \pm 16$ & $110 \pm 21$ & $101 \pm 17$ & $88 \pm 9$ \\
\hline 30 & $115 \pm 23$ & $102 \pm 16$ & $95 \pm 8$ & $102 \pm 13$ & $96 \pm 17$ & $88 \pm 19$ \\
\hline 50 & $141 \pm 21$ & $104 \pm 13$ & $110 \pm 9$ & $136 \pm 21$ & $114 \pm 19$ & $74 \pm 14$ \\
\hline 100 & $118 \pm 27$ & $74 \pm 8$ & $77 \pm 7$ & $124 \pm 17$ & $61 \pm 4$ & $71 \pm 12$ \\
\hline
\end{tabular}

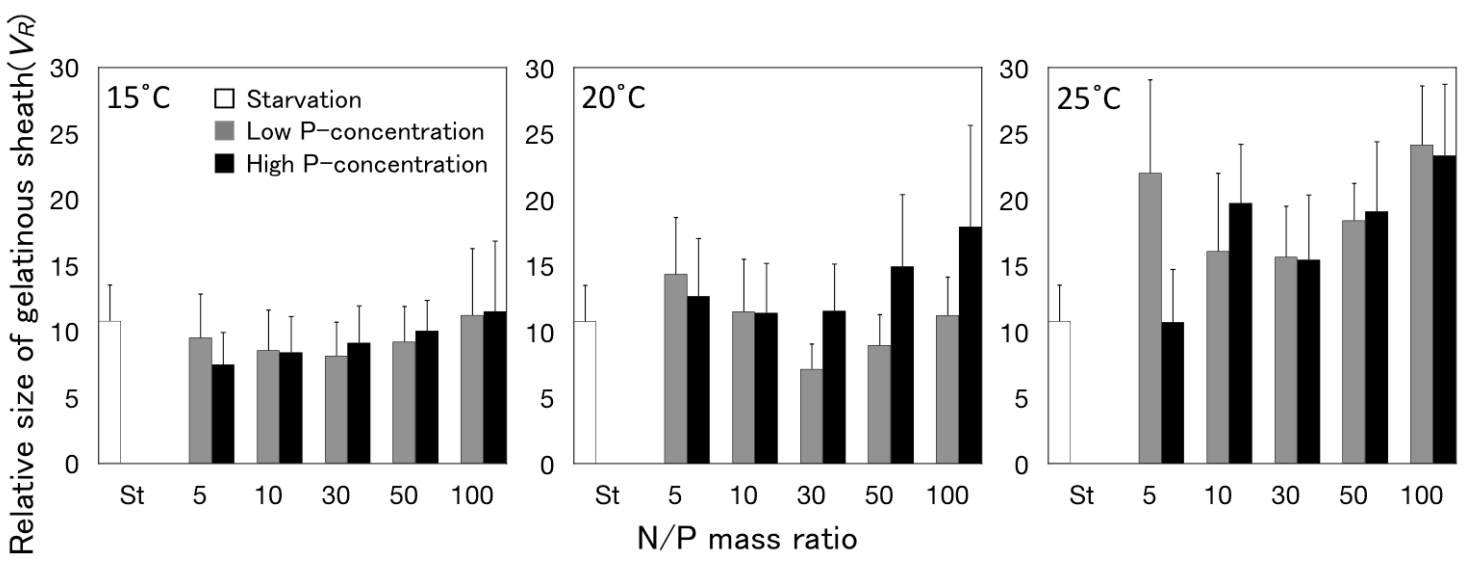

Fig. 3 - Size of the gelatinous sheath relative to the cellular biovolume $\left(V_{R}\right)$ as a function of the N/P mass ratio and water temperature. Starvation represents the end of pre-culture, low $\mathrm{P}$ concentration was $0.01 \mathrm{mg} \mathrm{P} / \mathrm{L}$ and high $\mathrm{P}$ concentration was $0.1 \mathrm{mg} \mathrm{P} / \mathrm{L}$ in the culture medium. Error bars indicate the standard deviations for triplicate cultures. 
Table 2 - Results of the multiple regression analysis. The predictor variables were water temperature (WT) $\left[{ }^{\circ} \mathrm{C}\right]$, nitrate concentration $(\mathrm{N})[\mathrm{mg} \mathrm{N} / \mathrm{L}]$, and phosphate concentration (P) $[\mathrm{mg} \mathrm{P} / \mathrm{L}]$. Dependent variables were gelatinous sheath volume $\left(V_{G}\right)$, cellular biovolume $\left(V_{C}\right)$, and relative gelatinous sheath volume $\left(V_{R}\right)\left[\mu \mathrm{m}^{3} /\right.$ cell].

\begin{tabular}{cccc}
\hline $\begin{array}{c}\text { Dependent } \\
\text { variable }\end{array}$ & $V_{G}$ & $V_{C}$ & $V_{R}$ \\
\hline Predictor variable & & & \\
WT & $50.4 \times 10^{3}(p=0.001)$ & $-2.91 \times 10^{3}(p=0.000)$ & $0.913(p=0.000)$ \\
$\mathrm{N}$ & $3.86 \times 10^{3}(p=0.048)$ & $-0.104 \times 10^{3}(p=0.268)$ & $0.061(p=0.002)$ \\
$\mathrm{P}$ & $-120 \times 10^{3}(p=0.359)$ & $-5.26 \times 10^{3}(p=0.935)$ & $-13.4(p=0.276)$ \\
Intercept & $249 \times 10^{3}(p=0.36)$ & $160 \times 10^{3}(p=0.000)$ & $-5.225(p=0.046)$ \\
\hline Adjusted $R^{2}$ & 0.37 & 0.407 & 0.702 \\
\hline
\end{tabular}

\section{DISCUSSION}

The specific growth rate of $S$. arctiscon increased with a rise in water temperature to a range of $15-25^{\circ} \mathrm{C}$ (Fig. 2). Thus, the cell division rate increased with a rise in water temperature. This suggested that a higher water temperature resulted in a lower $V_{C}$ because it avoided an excessive accumulation of photosynthetic organic carbon in the cell, which would have occurred with a faster cell division rate. Smaller phytoplankton usually have higher specific growth rates (Kagami and Urabe, 2001; Finkel et al., 2010). There may be a general relationship where the cell size of phytoplankton is inversely correlated with its specific growth rate, even in individuals of the same species.

The mass balance of organic carbon in the cell is expressed as follows:

$$
P_{\text {gross }}-R=M_{\text {syn }}+M_{e x}
$$

where, $P_{\text {gross }}$ is the gross production rate, $R$ is the respiration rate, $M_{s y n}$ is the biosynthesis rate, $M_{e x}$ is the extracellular discharge rate, and $P_{\text {gross }}-R$ is the net production rate. It is considered that $M_{s y n}$ and $M_{e x}$ are positively correlated with the specific growth rate and production rate of the gelatinous sheath, respectively. Thus, $V_{G}$ increases when the rate of increase of net production with a change in the cultural conditions is higher than that of $M_{s y n}$. Raven and Geider (1988) reported $\mathrm{Q}_{10}$ values for photosynthesis, respiration, and nitrate reductase activity of around 2.6, 2.0, and 1.8, respectively. The nitrate reductase activity correlates with the biosynthesis rate, so the $\mathrm{Q}_{10}$ values indicate that the increasing rate of net production with a rise in water temperature is higher than that of $M_{s y n}$. Thus, water temperature can increase $V_{G}$ by enhancing the net production rate more than $M_{s y n}$.

Geider et al. (1988) reported that the intracellular N/C ratio of phytoplankton had a positive relationship with the photosynthesis rate in the same light and temperature conditions. In the present study, the intracellular N/C mass ratio increased with an increase in the nitrogen concentration in the culture medium; therefore, the nitrate 
concentration was considered to have a positive effect on the gelatinous sheath volume through the enhancement of $P_{\text {gross }}$.

Recently, the annual mean total phosphorus concentration in the northern basin of Lake Biwa fluctuated around $0.08 \mathrm{mg} \mathrm{P} / \mathrm{L}$. Contrary to total phosphorus, the annual mean total nitrogen concentration increased from $0.25 \mathrm{mg} \mathrm{N} / \mathrm{L}$ in 1983 to $0.34 \mathrm{mg} \mathrm{N} / \mathrm{L}$ in 1996. But it decreased after 2003 and reached $0.24 \mathrm{mg} \mathrm{N} / \mathrm{L}$ in 2010 . As a result, annual mean N/P mass ratio also decreased from 49 in 1996 to 30 in 2010 (Shiga Prefecture, 2011). Therefore, the N/P mass ratio of 30 under low phosphorus concentration was almost equivalent to the current situation in the northern basin of Lake Biwa. If the total nitrogen concentration decreases further, the reduction of $V_{G}$ will be expected according to the regression model shown in Table 2. Thus, a decrease in nitrogen concentration might contribute to the control of organic pollution caused by gelatinous sheath in Lake Biwa (Ichise et al., 2010b).

\section{CONCLUSIONS}

In this study, we investigated the influence of the cultural conditions on the cellular biovolume $\left(V_{C}\right)$, gelatinous sheath volume $\left(V_{G}\right)$, and the relative size of the gelatinous sheath $\left(V_{R}\right)$ of $S$. arctiscon and its growth characteristics in laboratory culture. The results are summarized as follows:

(1) The optimum growth temperature for $S$. arctiscon was $25^{\circ} \mathrm{C}$. The responses of the specific growth rate to nitrate and phosphate concentrations resembled the Monod's equation. The half-saturation constants were estimated to be $K_{N}=0.076 \mathrm{mg} \mathrm{N} / \mathrm{L}$ for nitrate and $K_{P}=0.011 \mathrm{mg} \mathrm{P} / \mathrm{L}$ for phosphate.

(2) Water temperature had positive regression coefficients with $V_{G}$ and $V_{R}$, but a negative regression coefficient with $V_{C}$ at $p<0.05$. A higher water temperature resulted in a lower $V_{C}$ because it avoided the excessive accumulation of photosynthetic organic carbon in the cell, which would occur with a more rapid cell division rate.

(3) The nitrate concentration had positive regression coefficients with $V_{G}$ and $V_{R}$ at $p<$ 0.05 , but it had no significant regression coefficient with $V_{C}$. The intracellular N/C mass ratio increased with a rise in nitrogen concentration in the culture medium, so it was considered that $V_{G}$ was increased by the high photosynthesis rate because of the high intracellular $\mathrm{N} / \mathrm{C}$ mass ratio with a high nitrate concentration.

(4) The phosphorus concentration had no significant regression coefficients with all volumes at $p<0.05$.

\section{ACKNOWLEDGMENT}

This research was financially supported by the Environmental Research and Technology Development Fund (B-1102), Ministry of Environment, Japan.

\section{REFERENCES}

Belgrano A., Allen A. P., Enquist B. J. and Gillooly J. F. (2002) Allometric scaling of maximum population density: a common rule for marine phytoplankton and 
terrestrial plants. Ecological Letters, 5, 611-613.

Downing J. A. (1997) Marine nitrogen: phosphorus stoichiometry and the global N:P cycle. Biogeochemistry, 37, 237-252.

Finkel Z. V., Beardall J., Flynn K. J., Quigg A., Rees T. A. V. and Raven J. A. (2010) Phytoplankton in a changing world : cell size and elemental stoichiometry. Journal of Plankton Research, 32(1), 119-137.

Fogg G. E. (1983) The ecological significance of extracellular products of phytoplankton photosynthesis. Botanica Marina, 26(1), 3-14.

Geider R. J., MacIntyre H. L. and Kana T. M. (1998) A dynamic regulatory model of phytoplanktonic acclimation to light, nutrients, and temperature. Limnology and Oceanography, 43(4), 679-694.

Hagiwara T., Yagi O., Takamura Y. and Sudo R. (1984) Isolation of bacteria-free Microcystis aeruginosa from Lake Kasumigaura. Upgrading of anaerobic digestion of waste activated sludge by thermal pretreatment. Japan Journal of Water Pollution Research, 7(7), 437-442. (in Japanese)

Hall S. R., Smith V. H., Lytle D. A. and Leibold M. A. (2005) Constraints on primary producer $\mathrm{N}: \mathrm{P}$ stoichiometry along $\mathrm{N}: \mathrm{P}$ supply ratio gradients. Ecology, 86(7), 1894-1904.

Hsieh C. H., Ishikawa K., Sasaki Y., Ishikawa T., Ichise S., Yamamoto Y., Kuo T. C., Park H. D., Yamamura N. and Kumagai M. (2010) Phytoplankton community reorganization driven by eutrophication and warming in Lake Biwa. Aquatic Sciences, 72, 467-483.

Ichise S., Fujiwara N., Furuta S., Ikeda S. and Kishimoto N. (2010a) Analysis of Long-term variation in plankton etc. in Lake Biwa-Phytoplankton-. Annual Reports of Lake Biwa Environmental Research Institute, 6, 105-110. (in Japanese)

Ichise S., Furuta S., Okamoto T., Ohno T., Sakamoto M., Banba D. and Kishimoto N. (2010b) Gradually increasing dissolved organic matter in Lake Biwa and its relation with primary production. Proceedings of The 44th Annual Conference of Japan Society on Water Environment, March 15-17, Fukuoka, Japan. 371. (in Japanese)

Kagami M. and Urabe J. (2001) Phytoplankton growth rate as a function of cell size : an experimental test in Lake Biwa. Limnology, 2, 111-117.

Kumagai M. (2008) Lake Biwa in the context of world lake problems. Verhandlungen der Internationalen Vereinigung für Theoretische und Angewandte Limnologie, 30(1), 1-15.

Lange W. (1976) Speculations on a possible essential function of the gelatinous sheath of blue-green algae. Canadian Journal of Microbiology, 22, 1181-1185.

Nozaki K. (2002) Characteristics of primary production in the littoral zone of lake. Japanese Journal of Limnology, 63, 225-231. (in Japanese)

Raven J. A. and Geider R. J. (1988) Temperature and algal growth. New Phytologist, 110, 441-461.

Rhee G. Y. and Gotham I. (1981) The effect of environmental factors on phytoplankton growth: Temperature and the interaction of temperature with nutrient limitation. Limnology and Oceanography, 26(4), 635-648.

Sakamoto M. (2011) Limnological responses to changes in the thermal mixing regime in Lake Biwa associated with global warming. Aquatic Ecosystem Health and Management, 14(2), 214-218.

Sekino T., Genkai-Kato M., Kawabata Z., Melnik N. G., Logacheva N. P., Belykh O. I., Obolkina L. A., Bondarenko N. A., Khodzher T. V., Gorbunova L. A., Tanichev A. I., 
Yoshida T., Kagami M., Gurung T. B., Urabe J., Higashi M. and Nakanishi M. (2007) Role of phytoplankton size distribution in lake ecosystems revealed by a comparison of whole plankton community structure between Lake Bikal and Lake Biwa. Limnology, 8, 227-232.

Shiga Prefecture (2011) White paper on the environment 2011, Data book. Shiga Prefecture, 45-177. (in Japanese)

Smith V. H. (1979) Nutrient dependence of primary productivity in lakes. Limnology and Oceanography, 24(6), 1051-1064.

Suzuki K., Kishimoto N., Ichise S. and Furuta S. (2012) Growth characteristics and occurrence of Staurastrum dorsidentiferum var. ornatum (Charophyceae), a large green alga, in Northern basin of Lake Biwa, Japan. Journal of Japan Society on Water Environment, 35(11), 181-186. (in Japanese)

Tsuda T., Okamoto T., Nakamura T., Yada M., Sanuki N., Dohi M., Omoda M., Ichise S., Wakabayashi T., Aoki S. and Hara R. (2006) Long-term monitoring of vertical water quality basin of Lake Biwa. Journal of Japan Society on Water Environment, 29(9), 565-568. (in Japanese)

Urabe J., Sekino T., Nozaki K., Tsuji A., Yoshimizu C., Koitabashi T., Miyazaki T. and Nakanishi M. (1999) Light, nutrients and primary productivity in Lake Biwa : An evaluation of the current ecosystem situation. Ecological Research, 14, 233-242.

Yvon-Durocher G., Montoya J. M., Trimmer M. and Woodward G. (2011) Warming alters the size spectrum and shifts the distribution of biomass in freshwater ecosystems. Global Change Biology, 17, 1681-1694. 